\title{
Article \\ Effect of the Addition of Different Vegetal Mixtures on the Nutritional, Functional, and Sensorial Properties of Snacks Based on Pseudocereals
}

\author{
Ana Karen González-Calderón ${ }^{1}$, Natalia Alejandra García-Flores ${ }^{1}$, Ana Sofía Elizondo-Rodríguez ${ }^{1}$, \\ Mariana Zavala-López ${ }^{2}$, Silverio García-Lara ${ }^{2}$ D , Néstor Ponce-García ${ }^{3, *}$ and Anayansi Escalante-Aburto ${ }^{1,2, *}$
}

1 Department of Nutrition, Universidad de Monterrey, Av. Ignacio Morones Prieto 4500 Pte, San Pedro Garza García 66238, Mexico; ana.gonzalezc@udem.edu (A.K.G.-C.); natalia.garciaf@udem.edu (N.A.G.-F.); ana.elizondor@udem.edu (A.S.E.-R.)

2 Tecnologico de Monterrey, Escuela de Ingeniería y Ciencias, Ave. Eugenio Garza Sada 2501, Monterrey 64849, Mexico; mariana.zavala@itesm.mx (M.Z.-L.); sgarcialara@itesm.mx (S.G.-L.)

3 Faculty of Agricultural Sciences, UAEMex, Campus Universitario 'El Cerrillo', El Cerrillo, Piedras Blancas s/n, Toluca 50200, Mexico

* Correspondence: nponceg@uaemex.mx (N.P.-G.); anayansi.escalante@tec.mx (A.E.-A.)

check for updates

Citation: González-Calderón, A.K.; García-Flores, N.A.;

Elizondo-Rodríguez, A.S.; Zavala-López, M.; García-Lara, S.; Ponce-García, N.; Escalante-Aburto, A. Effect of the Addition of Different Vegetal Mixtures on the Nutritional, Functional, and Sensorial Properties of Snacks Based on Pseudocereals. Foods 2021, 10, 2271. https://doi.org/ $10.3390 /$ foods 10102271

Academic Editors: Costantino Fadda and Alessandra Del Caro

Received: 21 July 2021

Accepted: 2 September 2021

Published: 26 September 2021

Publisher's Note: MDPI stays neutral with regard to jurisdictional claims in published maps and institutional affiliations.

Copyright: (c) 2021 by the authors. Licensee MDPI, Basel, Switzerland. This article is an open access article distributed under the terms and conditions of the Creative Commons Attribution (CC BY) license (https:// creativecommons.org/licenses/by/ $4.0 /)$.

\begin{abstract}
Quick meals available in markets are popular among consumers. Generally, these products are not recognized as functional foods owing to nutrient-poor composition. In this study, energy snack bars were developed with different formulations, using puffed quinoa, amaranth, cacao liquor, and coconut oil, and the effects of the addition of commercial vegetal mixtures (VM) on nutritional and functional properties were assessed. VM addition showed significant effects on the protein, lipid, and fiber contents, phenolic compounds (PHC) content, and antioxidant activity of the snacks. The control snack showed higher levels of free and bound PHC. The oxygen radical absorbance capacity (ORAC) analyses recorded highest values of free PHC (9392.7 $\mu \mathrm{mol}$ TE/100 g dry weight) in PC65 (concentrate based on a combination of vegetal proteins), whereas the highest bound PHC levels of 47,087 and 46,531 $\mu \mathrm{mol}$ TE/100 g dry weight were observed in PC65 and the control snacks, respectively. Sensorial attributes assessment provided a high score on the hedonic scale, wherein panelists detected no differences among the samples. Altogether, the selection of non-conventional ingredients with high antioxidant activities emerged as a successful strategy to produce sensory acceptable meals.
\end{abstract}

Keywords: vegetal proteins; phenolic compounds; antioxidant activity; sensorial attributes; ancient grains

\section{Introduction}

In the past few years, snacks, with or without substantial nutritional value, have emerged as an alternative to quick meals. In fact, snacks are quite popular among consumers of all ages. Generally, most of these products are not recognized as functional foods, mainly due to their nutrient-poor composition. In the recent past, there has been a growing interest in the manufacturing of new types of snack bars using functional components. Therefore, such snack bars can also be included under the category of functional products, while keeping in mind consumers' acceptability and suitability of the product as ready to eat [1]. In general, functional foods are defined as dietary items that provide nutrients and energy, and at the same time positively modulate one or more targeted functions in the body, by enhancing certain physiological responses and/or reducing the risk of certain diseases [2].

Consumption of ancient foods has gained significant attention as these foods introduce different nutrient sources into the actual human diet, and thus assist in counteracting the high ingestion of ultra-processed foods [3]. The seed of quinoa, Chenopodium quinoa Wild, 
is a pseudocereal, which has been under cultivation for more than 5000-7000 years, in the Andean region and other South American countries. Since prehistoric age, quinoa has been used as a substitute cereal for consumption [4]. Quinoa seeds are endowed with exceptional nutritional and functional properties. This grain contains $\sim 14.8 \mathrm{~g} / 100 \mathrm{~g}$ of dietary fiber and $\sim 16.5 \mathrm{~g} / 100 \mathrm{~g}$ of proteins (with 20 amino acids, 10 of which are essential). Additionally, it is quite rich in unsaturated fatty acids, including linoleic acid (C18:2, $\omega-6)$ and $\alpha$-linolenic acid (C18:3, w-3) [5,6]. Functionally, quinoa seeds are gluten-free, and contain $~ 103.6 \mathrm{mg}$ of gallic acid equivalents (GAE)/100 g of dry weight (d.w.) of total polyphenols [7]. Interestingly, the high amounts of unsaturated fatty acids (66.9-76.53\%), total carotenoids index (496.1$738 \mu \mathrm{g} / \mathrm{g} \mathrm{d.w.)}$, and total tocopherols index (9.3-93.6 $\mu \mathrm{g} / \mathrm{g}$ d.w.) present in quinoa seeds has been previously shown to demonstrate a good correlation with antioxidant activity, evaluated using FRAP, oxygen radical absorbance capacity (ORAC), and DPPH assays [6,8].

Amaranth (Amaranthus ssp.) is a pseudo-cereal, which has been popularly consumed since the pre-Colombian age. Several previous studies have reported the presence of high nutritional value proteins and high content of lysine in amaranth $[9,10]$. Importantly, amaranth is characterized by total phenol content of $15.5 \mathrm{mg}$ GAE/100 g d.w., anthocyanin content of $83 \mathrm{mg}$ of cyanidin 3 glucoside/100 g d.w., and flavonoids content of $70.2 \mathrm{mg}$ catechin eq/100 $\mathrm{g}$ d.w. [11]. Cacao liquor (Theobroma cacao) is a rich source of both monounsaturated and saturated fatty acids. Oleic acid is one of the most important components of cacao liquor. Palmitic and stearic acids are the primary saturated fatty acids present in cacao. Additionally, cacao contains some minerals, including magnesium, copper, potassium, and iron. Among the polyphenolic compounds, catechins, anthocyanins, and proanthocyanidins are the most abundant class of compounds present in cocoa powder [12].

Substitution of animal proteins by vegetal proteins still remains controversial; however, a significant growth has been recorded in the market for vegan and vegetarian consumers. The 2015 Dietary Guidelines Advisory Committee maintained primary focus on higher dietary patterns of plant-based foods in their scientific report [13]. It was recommended that the empty calories contributed by added sugars should be replaced, in part, with a better variety of plant protein. Thus, the general perception related to plant protein has evolved over the past few years [14]. Initially, plant proteins were perceived as less nutritious and an incomplete source of essential amino acids, but now they are considered as a healthy alternative to fulfill protein needs and recommendations [15]. All the aforementioned ingredients are endowed with exceptional nutritional and functional properties, as reported in previous studies. In order to fulfill the sustainable objectives of the Food and Agricultural Organization [16], it is required to improve the nutritional and functional values of food products in the future.

Several commercially available snack bars are added with vegetal mixtures; however, just a few are assessed by scientific methods. The effect of the vegetal mixtures containing different compounds such as proteins in the nutritional and texture properties of snacks have been investigated by Malecki et al. [17]. Algae, pumpkin, sunflower, rice, soy, and hemp, were used as ingredients to produce high-protein bars. However, glucose syrup $(\sim 32 \% w / w)$ was added, considered a non-desirable component for a healthy diet.

Microbiological and sensory properties of diet bars elaborated with chia grain (Salvia hispanica L.) and soy protein were evaluated by Veggi et al. [18]. They concluded that the addition of chia seeds has a positive effect on the sensory characteristics of this type of product.

There are no scientific reports of the antioxidant assessment of snack bars containing only vegetal mixtures to our knowledge. Therefore, the present study aimed to evaluate the effect of the addition of different vegetal mixtures (VM) on the nutritional properties and phenolic contents of snacks prepared using non-conventional ingredients, with minimal processing. Additionally, the antioxidant activity and sensorial attributes of different snack samples were evaluated. 


\section{Materials and Methods}

\subsection{Materials}

Commercially available puffed quinoa, amaranth, cacao liquor, coconut oil, and coconut milk were used for the development of different formulations. In order to obtain different ingredient combinations and produce the energy snacks, three VM were used, namely Provita $C^{\circledR}$ (Nutrigrains ${ }^{\circledR}$, Monterrey, Mexico), an isolate based on a combination of vegetal proteins that contained $88 \%$ proteins, $7 \%$ carbohydrates, and $2 \%$ lipids, d.w.; Provita $\mathrm{C} 65^{\circledR}$, a concentrate based on a combination of vegetal proteins that comprised of $60 \%$ proteins, $38 \%$ carbohydrates, and $2 \%$ lipids, d.w.; and Probalance ${ }^{\circledR}$ (Nutrigrains ${ }^{\circledR}$, Monterrey, Mexico), a high dietary fiber ingredient that is based on the combination of a vegetal protein, containing $20 \%$ proteins, $40 \%$ carbohydrates, $35 \%$ dietary fiber, and $3 \%$ lipids, d.w. [19].

\subsection{Energy Snacks Production}

Several preliminary assays were performed to obtain the final formulation for a product with optimum sensorial characteristics, similar to the products commercially offered in the market. The snacks were prepared at the Gastronomy Laboratory of the University of Monterrey. The production of the bar samples was carried out as per the criteria of NOM-251-SSA1-2009 [20]. General methodology followed for the production of the energy snacks is shown in Figure 1. For confidentiality reasons, the proportion of the ingredients used in the production has not been reported in detail (patent application under process). The products were developed using four treatments: PC: Base formula + Provita $C^{\circledR}$; PC65: Base formula + Provita C65 ${ }^{\circledR} ;$ PB: Base formula + Probalance ${ }^{\circledR}$; and Control: Base formula without vegetal mixture (VM). The final products obtained after the elaboration of the energy snacks is shown in Figure 2, in particular, the products containing VM presented similar characteristics, except for the control snack.

\subsection{Nutritional Analysis}

Sample products obtained from each treatment were ground into a fine powder using a blender (Moulinex, model 980-18, France), and passed through a sieve (60 US). The resulting samples were transferred to polyethylene bags, sealed, and stored in dark at $5{ }^{\circ} \mathrm{C}$ in a refrigerator until used further. All nutritional analyses were conducted using the methods approved by AACCI [21]. The moisture content was calculated using AACC method 44-01.01. For the assessment of fat acidity, AACC method 02-01.02 was used, while ash content or inorganic material was measured using AACC method 08-01.01. The protein content was evaluated using AACC method 46-10.01. Total sugars and reduced sugars were quantified according to the procedure previously described by Eynon and Lane [22]. Total dietary fiber was assessed using a commercially available assay Kit (Sigma Aldrich, St. Louis, MO, USA), which was based on the 958.29 AOAC method. It combined enzymatic and gravimetric parameter for the determination of fiber content. All assays were performed in triplicates. Total calories by portion (30 g of product) were calculated using Equation (1), as per the specifications described by Kraisid et al. [23].

Calories per portion $(\mathrm{kcal} / 30 \mathrm{~g})=[(\mathrm{g}$ of carbohydrates $+\mathrm{g}$ of protein $) 4+(\mathrm{g}$ of lipids $) 9]$ 


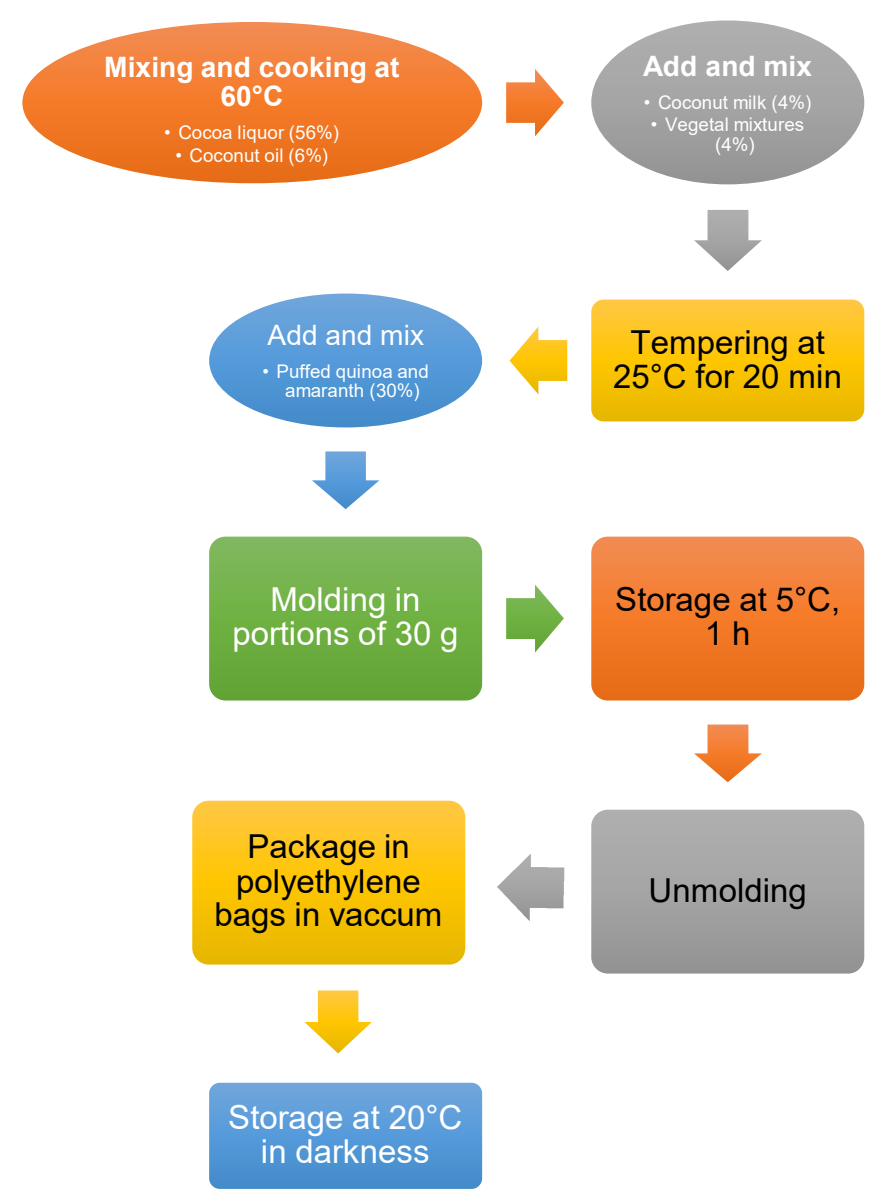

Figure 1. General methodology followed for the development of energy snacks with vegetable mixtures.

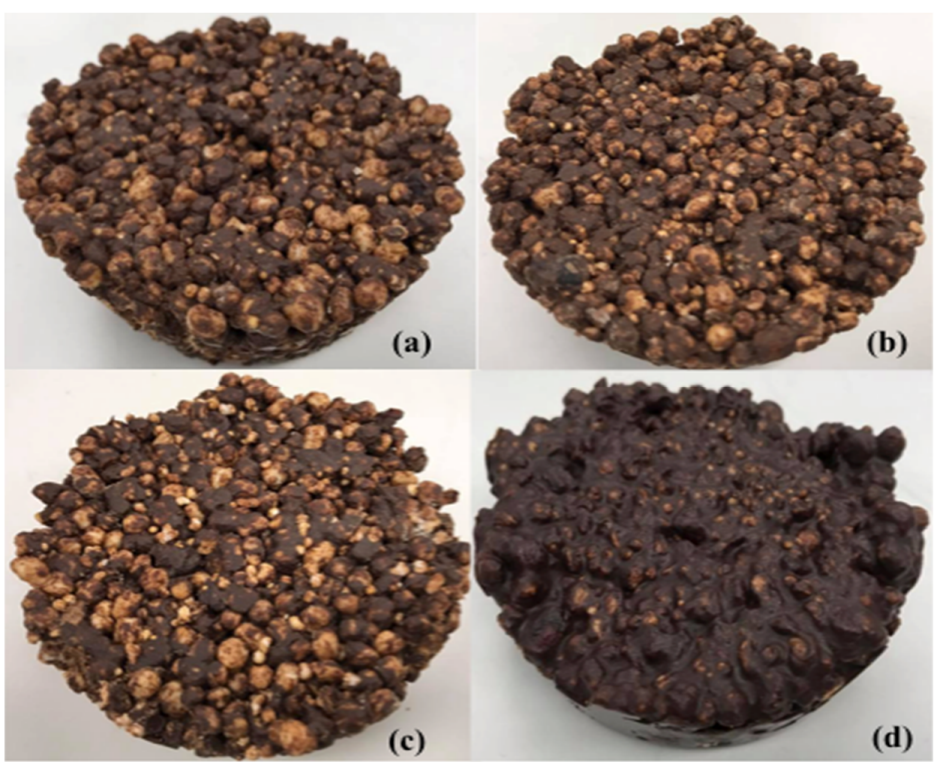

Figure 2. Samples of different energy snacks produced using different vegetable proteins mixtures. (a) PC, (b) PC65, (c) PB, and (d) control (without protein mixture). 


\subsection{Determination of Phenolic Acids (PHC, Bound and Free)}

\subsubsection{Extraction of PHC}

A microscale method was used to assess bound and free PHC present in the samples, according to the procedure previously described by Zavala-López and García-Lara [24]. To extract soluble (free) PHC, $50 \mathrm{mg}$ of defatted, dehydrated, and homogenized sample of each bar was mixed with $0.7 \mathrm{~mL}$ of $80 \%$ methanol. Further, the samples were incubated at $25^{\circ} \mathrm{C}$ for $2 \mathrm{~h}$ with continuous stirring at $450 \mathrm{rpm}$. After sedimentation for $15 \mathrm{~min}$, the supernatant was carefully removed and the sampled was incubated at room temperature for $24 \mathrm{~h}$ to ensure complete solvent evaporation. After $24 \mathrm{~h}, 0.7 \mathrm{~mL}$ of solvent ( $80 \%$ methanol) was added to the residue pellet, and the sample was vortexed at $2500 \mathrm{rpm}$ for $5 \mathrm{~min}$. The bound PHC were obtained from the soluble fraction of the residue pellet. Briefly, $2 \mathrm{M} \mathrm{NaOH}$ was added to the pellet and volume was reduced from $10 \mathrm{~mL}$ to $0.5 \mathrm{~mL}$. Alkaline hydrolysis was performed at $90^{\circ} \mathrm{C}$, with constant agitation at $500 \mathrm{rpm}$. Following this, acidification $(\mathrm{pH} 2)$ was achieved by the addition of $0.5 \mathrm{~mL}$ of $2 \mathrm{M} \mathrm{HCl}$. To remove lipid, $0.8 \mathrm{~mL}$ of n-hexane was added to the sample, which was vortexed at $2500 \mathrm{rpm}$ for $5 \mathrm{~min}$. The upper hexane layer was discarded, and the washing procedure using n-hexane was repeated twice. Following this, the bound PHC were recovered using ethyl acetate. Briefly, $0.8 \mathrm{~mL}$ ethyl acetate was added, and the sample was vortexed at $2500 \mathrm{rpm}$ for $5 \mathrm{~min}$. Further, the sample was incubated at $25^{\circ} \mathrm{C}$, and aforementioned steps of constant agitation and centrifugation were performed. Next, ethyl acetate was evaporated, and the resulting dry residue was re-suspended in $200 \mu \mathrm{L}$ of $50 \%$ methanol. Finally, the suspension was filtered through a $0.45 \mu \mathrm{m}$ GHP membrane and a Nylon filter. Both the extracts for soluble and bound PHC were stored at $-20{ }^{\circ} \mathrm{C}$ until used for further analysis.

\subsubsection{Quantification of Free and Bound PHC}

The amount of free and bound PHC were quantified according to the procedure described by Zavala-López and García-Lara [24]. In particular, the Folin-Ciocalteu assay was used for the assessment, wherein $\mathrm{Na}_{2} \mathrm{CO}_{3}(7.5 \% \mathrm{w} / v)$ was used to neutralize the reaction. Following this, the sample was incubated at room temperature for $2 \mathrm{~h}$. PHC were quantified in a microplate reader at $765 \mathrm{~nm}$, with gallic acid used as a standard. The results were expressed as mg of gallic acid equivalents / $100 \mathrm{~g}$ of dry weight (mg of GAE/ $100 \mathrm{~g}$ d.w.).

\subsection{Assessment of ORAC}

Antioxidant capacity of the energy snacks was determined by the method proposed by Bergvinson and García-Lara [25]. Briefly, the samples were diluted by 50 or 400 -fold, by addition of phosphate buffer ( $\mathrm{pH}$ 7.4), and extracts were obtained to separate soluble and bound phenolics. The resulting extracts were read in a microplate, wherein $25 \mu \mathrm{L}$ of 2, 20-azobis (2-methylpropionamidine) dihydrochloride was injected as peroxyl radical generator, every $2 \mathrm{~min}$ for $1 \mathrm{~h}$, prior to the fluorescence measurement. The resulting data was presented as $\mu \mathrm{mol}$ of Trolox equivalents per $100 \mathrm{~g}$ of dry weight ( $\mu \mathrm{mol} \mathrm{TE} / 100 \mathrm{~g}$ d.w.).

\subsection{Sensorial Evaluation}

Samples for each formulation were tested for the acceptance of the product. Briefly, 50 non-trained panelists, aged 17-45 years and belonging to both sexes, were included as participants. Prior to the commencement of the test, all the participants were required to sign an agreement and confidentiality documents, which described the conditions of the assessment and acceptance of the utilization of the resulting data anonymously. For testing, individual spaces with adequate illumination were allotted at the Laboratory of Gastronomy, Universidad de Monterrey. The samples of the snacks were presented in a disposable tray at room temperature $\left(25^{\circ} \mathrm{C}\right)$. Each sample was randomly assigned a three-digit code, corresponding to four different samples, namely the control sample (no VM added), Provita $C^{\circledR}$, Provita $C 65^{\circledR}$, and Probalance ${ }^{\circledR}$. The order of the presentation was also assigned randomly. Prior to the evaluation and in-between the sample testing, 
the panelists were instructed to clean their mouths (tastebuds) with table water to remove any residual flavor. Besides this, the panelists were suggested to clean their sense of smell with coffee (contained in a glass bottle), by aspiring its aroma. A hedonic evaluation was structured with five points, scored on a scale varying from $0-5$, where " $0=$ extremely dislike" and " $5=$ extremely like." The characteristics (attributes) evaluated by the panelists included surface appearance, odor, flavor, consistency, and crunchiness [26,27].

\subsection{Experimental Design and Statistical Analyses}

The present study involved a totally randomized experiment. To assess the effect of processing factors, statistical analysis was performed using ANOVA, with confidence interval of 95\%. Duncan's Multiple Range Test was used $(p \leq 0.05)$ to assess the statistical differences between the means of various treatments. Statistical analyses were assessed using the $S A S^{\circledR}$ software, version 9.3 (SAS Institute Inc., Cary, NC, USA).

\section{Results and Discussion}

\subsection{Nutritional Properties}

The nutritional components of the energy snacks are depicted in Figure 3. The moisture content of the samples remained unaffected by the addition of VM. For all samples, the moisture content was recorded to be in the range of $4.7-5.3 \%$, which was in concordance with the values for a similar snack formulation reported by Caipo et al. [28]. Additionally, the results for the ANOVA analyses $(p=0.7060)$ also showed that there were no statistically significant differences among the four formulations of snacks. The low moisture content of the snacks could be attributed to relatively high temperatures and interaction of the starch, present in the pseudo-cereals, with the lipids present in the cacao liquor and the coconut milk [29]. In general, lipids are hydrophobic in nature, and thus cannot interact with water owing to lack of formation of dipoles. The presence of lipids does not allow the adsorption of relative humidity from the environment by the snacks [30].

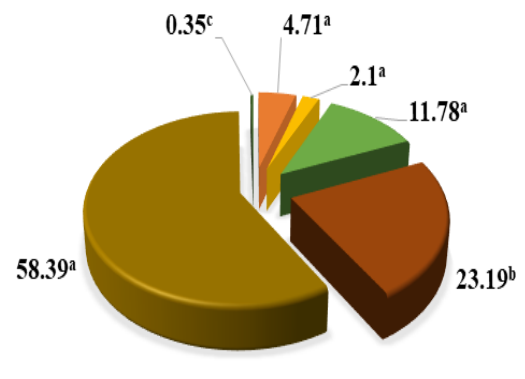

$151.4^{\mathrm{a}}$ calories

(a)

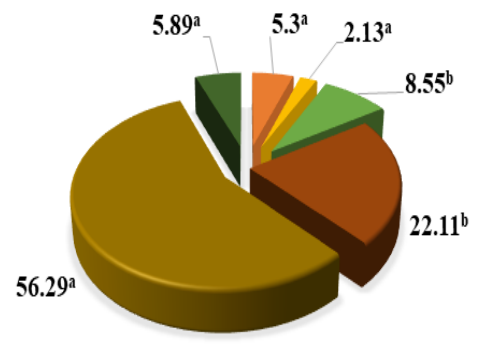

$135.5^{\mathrm{b}}$ calories

(c)

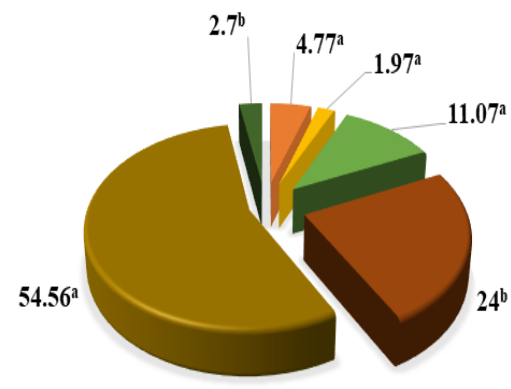

$143.3^{\text {ba }}$ calories

(b)

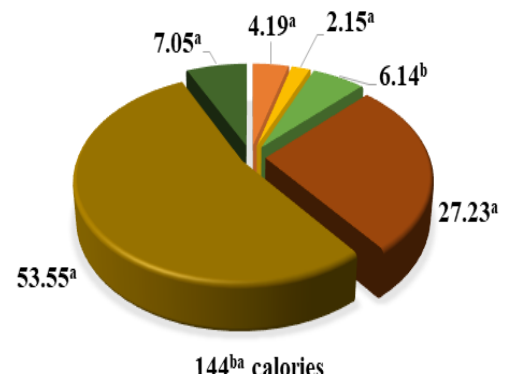

(d)

Figure 3. Chemical and nutritional analyses of the energy snacks, prepared with vegetable protein mixtures. (a) PC, (b) $\mathrm{PC} 65^{\circledR}$, (c) PB, and (d) control. Different letters among components are statistically different $(p<0.05)$. Total calories were calculated for a $30 \mathrm{~g}$ portion. 
As expected, the primary macronutrient present in the developed formulations was carbohydrates, which was measured to be in the range of $53-58 \%$. Results for the ANOVA analyses showed that the addition of VM conferred no significant effect $(p=0.1285)$ on this parameter. Total carbohydrates recorded in the formulations, developed in the present study, were lower as compared to the energy bar developed by Caipo et al. [28], which comprised of quinoa, amaranth, and cañihua (Chenopodium pallidicaule) $(>64 \%)$. Interestingly, these values were similar to those reported for a nutritive cereal bar that contained egg albumin and milk powder (57\%) [31].

The complex carbohydrates present in foods, such as starch, are considered to be beneficial for human health, especially for sedentary populations that are at risk of chronic diseases [32]. Quinoa contains starch comprising of units of D-xylose, D-ribose, D-galactose, and maltose, which have a low glycemic index. However, it also contributes to a high glycemic response, and can be considered as an energy product owing to the presence of saccharose and fructose components [33]. This is concerning with regard to the puffing process of quinoa, as it can modify the chemical structure of starch and improve its digestibility via gelatinization of starch and degradation of dietary fibers [34,35].

For the content of total and reduced sugars, the ANOVA analyses showed that the addition of VM did not have any significant effect on these two parameters $(p=0.2259$ and $p=0.5275$, respectively). The analysis of these parameters is particularly essential as its consumption is associated with a rise/reduction in the blood glucose levels. Total sugars were recorded to be $\sim 11.8 \%$ and $\sim 13.6 \%$ for PB sample and PC65 snacks, respectively. The last treatment probably resulted in the highest value as this protein concentrate contained $\sim 40 \%$ of carbohydrates, as per the technical and nutritional specifications [19]. The amount of total sugars was recorded to be in the range of $8.6 \%$ for PC 65 and $10.4 \%$ for the control samples. In general, simple sugars (monosaccharides) are positively correlated to hyperglycemia owing to their rapid absorption [36]. All energy snacks produced in this study showed significantly lower amounts of total and reduced sugars as compared to the commercial cereal-based meals, which contain up to $30 \mathrm{~g}$ per $100 \mathrm{~g}$ of product [37].

For protein content, the ANOVA analyses showed that the addition of VM incurred a high and statistically significant effect $(p=0.0006)$. In particular, the samples PC and PC65 presented the highest amounts of this macronutrient as compared to PB and the control. It was inferred that the samples of the snacks showing highest values of protein were those that were elaborated with VM containing more crude proteins. For instance, Provita $\mathrm{C}^{\circledR}$ and Provita $\mathrm{C} 65{ }^{\circledR}$ contained $88 \%$ and $60 \%$, respectively, of this compound in their original formulas. This was followed by Probalance ${ }^{\circledR}$, which contained $20 \%$ of this compound [19]. This is in agreement with the results obtained in the present study, and corroborated that the addition of this type of formulations into the bars can be used a promising alternative to increase the protein content for consumers with special nutritional needs. The protein content present in the energy snack samples, reported in the present study, was similar to the products produced using animal protein sources or similar products, which were aimed at increasing the nutritional quality [38]. Nevertheless, the amino acid profile of quinoa makes them an excellent alternative to improve the nutritional value of such kinds of products. Also, the protein contents recorded in the developed energy snacks were higher as compared to the cereal (mixture of rice and oat flakes) snack reported by Srebernich et al. [39], which comprised of acacia gum, inulin, and sorbitol, with protein content in the range of 3.8-3.9\%. The Food and Agriculture Organization [40] has recommended the consumption of $1 \mathrm{~g} / \mathrm{kg} /$ day of protein to fulfill the daily requirements of this nutrient in adults (aged $>8$ years). Thus, the consumption of $30 \mathrm{~g}$ of the developed product will provide $3 \mathrm{~g}$ of proteins, resulting in the fulfillment of $6 \%$ of the daily protein requirement for an adult of $50 \mathrm{~kg}$.

The ANOVA analyses showed that the content of lipid content was also significantly affected by the addition of VM in the snacks $(p=0.0444)$. As expected, the control bar was characterized by the highest amount of lipids, and no statistically significant differences were recorded among the other snacks' samples upon VM addition. All samples 
presented more elevated amounts of fats as compared to other products. However, these macronutrients were majorly contributed by cacao liquor, quinoa seeds, and coconut milk. In particular, the lipid content in the energy snacks comprised of monounsaturated (C15:1, C16:1, C17:1, C18:1, and C:20:1), polyunsaturated (C18:2 and C18:3), and small amounts of saturated fatty acids (C12:0, C14:0, C15:0, C16:0, C17:0, C18:0, C20:0, and C22:0). The ingestion of unsaturated fatty acids has been previously shown to affect cardiovascular health, via reduction of cholesterol and low-density lipoproteins in the blood [41].

Despite the high amounts of unsaturated fatty acids, the ratio of $\omega-6 / \omega-3$ is important for further analysis, particularly to measure the contribution toward the potential benefits, such as antioxidant activity [5]. The contribution of lipids to the diet should be able to achieve $30-35 \%$ of the total calories intake per day. The consumption of $30 \mathrm{~g}$ of a PC snack provided $7 \mathrm{~g}$ of lipids (63 calories). Based on a 2000 calorie diet advised for an adult, it constituted $10.5 \%$ of the recommended fats intake (600 calories, 30\%) [42].

The results for the ANOVA analysis showed that total dietary fiber content was significantly affected by the addition of VM $(p=0.0002)$. Similarly, multiple mean comparison analysis demonstrated that the control and PB snacks were characterized by the highest values for the total dietary fiber content. In particular, some of the ingredients, namely quinoa, amaranth [43], and coconut milk are known to contain high amounts of dietary fiber, which contributed to the observed high values in the control snack. On the other hand, PB snack showed high dietary fiber content when compared with PC and PC65. This could be attributed to the presence of $\sim 35 \%$ of dietary fiber in PB vegetal protein mixture, according to the datasheet [19]. Considering the importance and benefits of total dietary fiber in health, its daily consumption must reach $25 \mathrm{~g} /$ per day, based on a 2000 calorie diet [44]. Thus, consumption of $30 \mathrm{~g}$ of a PB snack provides $1.8 \mathrm{~g}$ of dietary fiber, combined with other sources of these nutrients that further assist in proper functionality of the gastrointestinal system.

For the assessment of inorganic material (ash content), the ANOVA analyses showed that the addition of VM did not show any significant effect on the total trace elements content ( $p=0.7255)$. Thus, no differences were recorded among the snack formulations for this parameter. However, values of inorganic material were recorded in the range of $1.9-2.1 \%$, and the highest value was observed for the control snack. This could be attributed to the presence of high amounts of trace elements in pseudo-cereals as well as coconut milk and cocoa liquor, which are considered to be a good source of phosphorous, magnesium, potassium, calcium, zinc, and iron $[45,46]$. Despite the fact that the snacks were prepared only with vegetal foods, inorganic material content was higher as compared to other products prepared using animal food ingredients and additives, such as those reported by Sant'Ana et al. [38]. Although the developed snacks did not highlight exclusively from different formulations in terms of their inorganic contents, these snacks could be considered as a good source of trace elements, and thus could be used as an alternative for vegetarian and vegan consumers.

In terms of total caloric values per $30 \mathrm{~g}$ portion of the snack (Figure 3), the ANOVA analyses showed that the addition of VM conferred significant effect on this parameter $(p=$ 0.0224). Particularly, PC snack was characterized by the highest caloric content. However, the control and PC65 samples could be considered statistically equal. Interestingly, PB snacks displayed the lowest $(p<0.05)$ caloric content when compared with other samples. In a previous study, Green et al. [45] analyzed a total of 171 snack foods, and sorted them into several types (including "healthy" and "unhealthy"), such as formulated bars, cornbased bars, granola bars, and others. The nutritional quality and caloric values (energy content) of these snacks were reported in the range of 76-214 calories per portion. The snacks described in the present study provided caloric content similar to the products offered in the market; however, the nature of the constituting ingredients ensured a highly added nutritional value. Some of the previous studies have established that whole foods, high in protein and fiber, and whole grains enhanced satiety when consumed as a snack [46]. For the energy snacks, developed in the present study, calories per portion were slightly 
higher as compared to the nutritive cereal bars reported by Sant'Ana et al. [38], produced using egg white, milk powder, honey, soybean, and sucrose (121.2 calories per portion).

Lastly, the consumption of any energy snack developed in this study would provide a calorie intake of 135.5-151.4 calories per $30 \mathrm{~g}$ portion, which is equivalent to $6.7-7.5 \%$ of calories based on a 2000 calorie diet. However, the snacks could be regarded as hypercaloric product, considering the small amount of portion $(30 \mathrm{~g})$. Thus, further analysis should be considered to reduce the caloric content of the developed samples.

\subsection{Contents of Total, Free, and Bound PHC in the Energy Snacks}

Unfortunately, no information is available regarding the daily dosage of specific antioxidants compounds, such as PHC [47]. However, regular intake of antioxidants is known to play an essential role in reducing the risk of certain non-communicable diseases $[48,49]$. The ANOVA analysis showed that the addition of different VM to the snacks conferred a significantly high impact on the contents of free $(p<0.0001)$ and bound PHC $(p<0.0001)$.

Figure 4 depicts total, free, and bound PHC present in the energy snacks. For the control snack, higher content of bound PHC (1366 mg of GAE/100 g d.w.) was recorded, which could be attributed to higher content of cacao liquor, coconut milk, and oil, when compared with other formulations [12,50]. PB snack contained $1169.3 \mathrm{mg}$ of GAE/100 g d.w., whereas PC65 and PC snacks showed the lowest values for this parameter $(p<0.05)$, with 1010.4 and $1044.1 \mathrm{mg}$ of GAE/100 g d.w., respectively. The highest values for free phenolic acid content were recorded in the control (520.7 mg of GAE/100 g d.w.), PB (508.6 mg of GAE/100 g d.w.), and PC (514.5 mg of GAE/100 g d.w.) snacks. PC65 snack showed a significantly lower value ( $258.5 \mathrm{mg}$ of GAE/100 g d.w.) when compared with other samples. These effects could be contributed by interaction between proteins and free PHC. Energy bars prepared with Probalance ${ }^{\circledR}$ (containing 20\% of proteins) and the control sample showed the lowest concentrations for protein content (Figure 3). The latter could have contributed to the observed improvement in the quantification of free phenol molecules, as the aforementioned interactions between proteins and free phenol would not have occurred in the samples with comparatively lower protein contents.

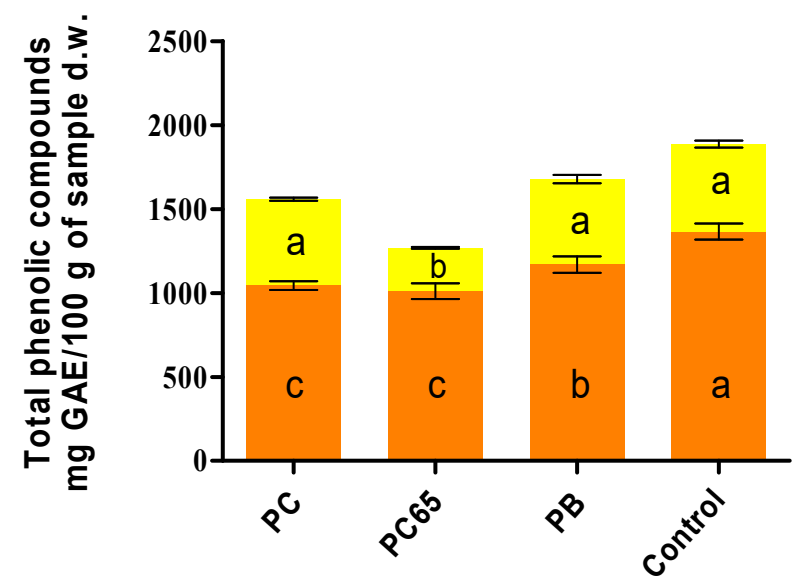

Bound phenolic compounds Free phenolic compounds

Figure 4. Contents of total, free, and bound phenolic compounds in the energy snacks. Different letters present in the same column color are statistically different $(p<0.05)$.

To accomplish a discussion and effectively compare the data with previous studies, the total phenolic acid content was calculated in terms of the sum of free and bound compounds. Nevertheless, it is important to consider that other type of compounds or molecules could have reacted during the analysis, which might have affected the results [51,52] [Melini 2021, Carciochi 2016]. In such a case, even Folin-Ciocalteu assay could be a limiting factor in the present study. Thus, the present data was compared with studies that utilized the same method for the quantification of PHC in similar samples. However, the double extraction 
process used for these compounds could have also resulted in a significant increase in their respective concentration. In this regard, the control, PC, PB, and PC65 contained $1886.7,1558.6,1677.9$, and $1268.9 \mathrm{mg}$ of GAE/100 $\mathrm{g} \mathrm{d}$.w., respectively. In comparison to this, the results for some of the snack samples (the control and PB) were found to be higher as compared to the cereal bars reported by Marques et al. [53], which were prepare with flours of acerola residues, enriched with antioxidant substances and fiber,. For these cereal bars, the content of phenolic compounds was recorded in the range 330-1600 mg of GAE/100 g d.w. of the product. However, these formulations also utilized brown sugar as an ingredient, which was not desirable. A similar tendency was recorded for values of total phenolic compounds for vegetable-enriched corn-based extruded snacks reported by Bisharat et al. [54]. In particular, total phenolic contents were recorded in the range of 15-25 mg of GAE/100 g d.w. for broccoli enriched extrudates and 30-50 mg of GAE/100 g d.w. for olive paste enriched extrudates.

Similarly, Silva Carvalho and Conti Silva [55] evaluated the total phenolic compounds for cereal bars formulated with banana peel flour, and reported values between $87-419 \mathrm{mg}$ GAE/100 g for seven different formulations, which contained variable amounts of rice flakes, oat flour, and banana peel flour. Ahmed and Abozed [56] developed a functional and novel snack enriched with Hibiscus sabdariffa by-product, with the aim to increase antioxidant activity and phenolic contents. The study reported total phenolic contents in the range of 599-1757 mg GAE/100 g. The results for the present study were considerably higher, and this attributed to the nature of the main ingredients used in the energy snacks. It has been previously reported that cocoa powder is rich in polyphenols, such as (+)catechin, (-)-epicatechin, oligomers of these monomeric base units, namely procyanidins, and anthocyanidins. It is also known to contain monomers to tetradecamers of other similar compounds [57]. Besides this, indigenous grains usually contain high amounts of flavonoids and other phenolic compounds. For instance, quinoa grains have been shown to contain caffeic acid, ferulic acid, p-coumaric acid, p-OH-benzoic acid, and vanillic acid [10]. In addition to the components found in quinoa, amaranth seeds also contain synaptic acid, protocatechuic acid, and some betacyanins (amaranthine, iso-amaranthine, and betanin) [9]. Additionally, the extraction method could have possibly influenced the concentration values of phenolic compounds in the snacks developed in the present study.

In addition to this, it is important to assess the interaction of phenolic compounds with vegetal protein fractions [58]. Such reactions could possibly occur during food processing, and the formation of complexes between phenolic compounds (ferulic acid, catechin, and similar compounds) and protein fractions present in cereals and pseudocereals (albumins, globulins, prolamins, and others) might be observed [59]. Such interactions could in turn affect the functionality, bioavailability, and physiological activity of the products [60]. Some of the inhibitory effects of phenolic compounds on the digestive process of food with high energy density ingredients, like carbohydrates and lipids, are considered to be beneficial if consumed in weight-controlled regimes. However, the inhibition of protein digestion is not desirable as it would result in a reduction in the bioavailability of amino acids, which would further affect the nutritional status of the consumers [61].

\subsection{ORAC Analyses in the Energy Snacks}

Figure 5 depicts the results of ORAC analyses for free and bound phenolic compounds present in the developed snacks. Since the values for the content of bound phenolic compounds were higher (Figure 4), the ORAC values were also recorded to be higher as compared to free PHC, that too in a directly proportional manner. The ANOVA results showed that the addition of VM had a significantly high impact on ORAC for both free $(p=0.0001)$ and bound $(p=0.0009)$ phenolic compounds of the samples. 


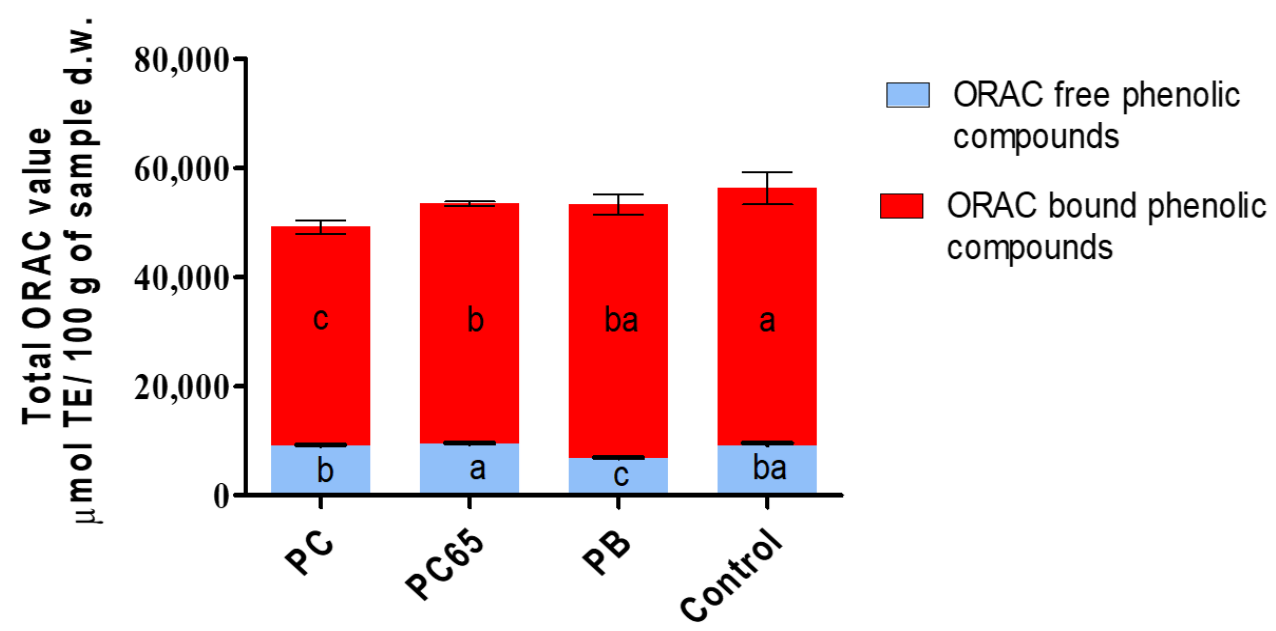

Figure 5. ORAC values for the contents of total, free, and bound phenolic compounds present in the energy snacks. Different letters present in the same column color are statistically different $(p<0.05)$.

For free phenolic compounds, PC65 snack showed highest ORAC value of $9392.7 \mu \mathrm{mol}$ TE/100 g d.w., whereas the lowest value was recorded for PB snack, with ORAC value of $6769.9 \mu \mathrm{mol} \mathrm{TE} / 100 \mathrm{~g}$ d.w. No statistically significant differences $(p<0.05)$ were recorded for the ORAC values of the control snack when compared with PC and PC65 snacks. For bound phenolic compounds, PC65 and the control snacks showed the highest $(p<0.05)$ ORAC values of 47,087 and 46,531 $\mu \mathrm{mol} \mathrm{TE} / 100 \mathrm{~g}$ d.w., respectively. In comparison to these, PC snack sample showed the lowest ORAC value $(40,158 \mu \mathrm{mol}$ TE/100 g d.w.) for bound phenolic compounds.

To accomplish a discussion and compare the obtained data with other studies, the total ORAC values for the snacks were calculated in terms of the sum of ORAC for free and bound phenolic compounds. Interestingly, the control snack accounted for the highest capacity with 56,279.3 $\mu \mathrm{mol}$ TE/100 g d.w; followed by PC65 snack with $56,479.7 \mu \mathrm{mol} \mathrm{TE} / 100 \mathrm{~g}$ d.w., PB snack with 53,293.9 $\mu \mathrm{mol}$ TE/100 g d.w., and PC snack with $49,192.9 \mu \mathrm{mol} \mathrm{TE} / 100 \mathrm{~g}$ d.w. Indirectly, it could be inferred that protein-PHC interactions could have affected the values for antioxidant capacity [58], especially for the bars containing highest amounts of protein (Figure 3), which resulted in lower ORAC values for PC samples produced using VM with minimum protein concentration. Thus, higher the protein content, lower would be the content of bound PHC and ORAC values.

Antioxidant activity of the produced snacks was found to be very different from the cereal bars reported by Rosales et al. [62], produced with Merlot/Cabernet Sauvignon grape seed flour, clover honey, oat flakes, pure cane sugar, vegetable oil, and cinnamon. The study reported antioxidant activity of 513-1103 $\mu \mathrm{mol}$ TE/100 g d.w. for cereal bars produced with Merlot grape seed flour as an antioxidant powder. These values were extremely lower as compared to the energy snacks developed in the present study, with exception of the control snack that corresponded to $1.9 \%$ of the antioxidant activity. Silva Carvalho and ContiSilva [55] reported antioxidant activity values in a range of 60-341 $\mu \mathrm{mol} \mathrm{TE} / 100 \mathrm{~g}$ d.w. for cereal bars formulated with banana peel four, evaluated using the ABTS + method. These values were extremely inferior when compared with the snacks developed in the present case. A similar trend was reported by Laokuldilok et al. [63], wherein encapsulated turmeric extracts were added to extruded cereal snacks to increase their antioxidant activity. Total phenolic compounds were very low $(662-207 \mu \mathrm{mol}$ TE/100 g) as compared to those reported in the present study.

The occurrence of extremely high values for both the quantification of phenolic acid compounds and ORAC determinations could be attributed to the enhanced separation during the extraction of free and bound phenolic acid compounds in the samples. Thus, higher radical scavenging activity was observed during the assays. The quantification of relative content of bioactive compounds and assessment of interactions between these 
molecules and other food matrix nutrients represent the main steps that are required for the determination of total antioxidant capacity and, consequently, evaluation of potential health benefits [64].

\subsection{Sensory Attributes}

For the evaluation of sensory attributes, 50 panelists (aged 17-45 years) belonging to both genders (66\% women and $34 \%$ men) were recruited. The results for the assessment of sensory attributes are presented in Figure 6.

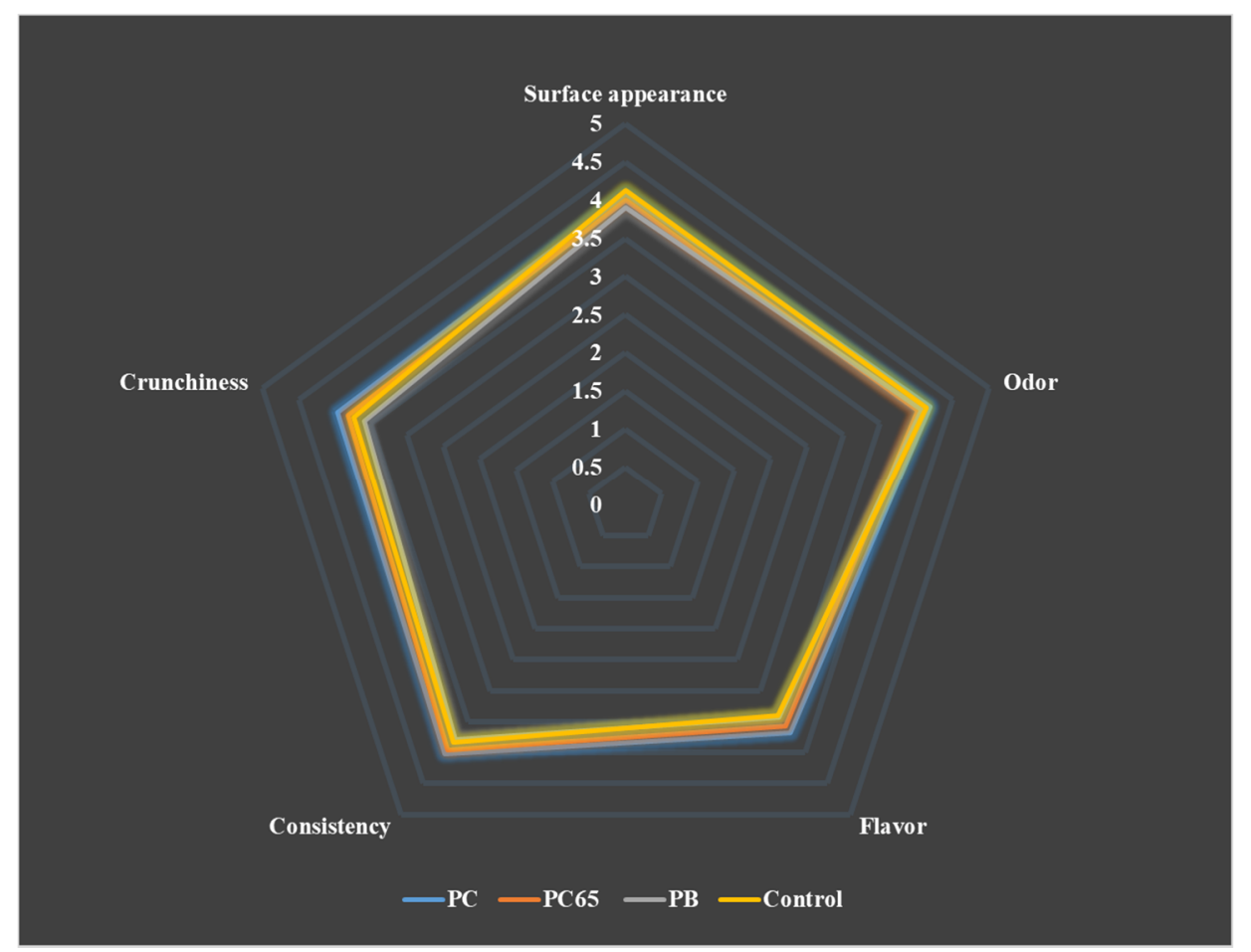

Figure 6. Evaluation of the sensory attributes of the snack bars. Here, $1=$ "dislike extremely", 2 = "dislike slightly", 3 = "neither like nor dislike", $4=$ "like slightly", and $5=$ "like extremely".

No statistically significant differences were recorded among sensory attributes of four formulations $(p>0.05)$; however, flavor and crunchiness showed highest values for standard deviation. For four samples that were evaluated, average values were recorded between 3.4 and 4.1, which corresponded to "neither like nor dislike" and "like slightly," respectively. The trend showed that PC snack was highly accepted by the panelists, with an overall average value of 3.95. None of the samples received the maximum scale punctuation (5, "like extremely"). This suggested that formulations must be improved further to increase the score in sensory analysis, even though all the snacks could be considered as an acceptable meal option as per current scoring.

\section{Conclusions}

The present study achieved the development of snacks with an acceptable nutrient quality, which were prepared using ancestral pseudo-cereals, vegetal mixtures, and lipid sources. An easy manufacturing method was utilized for the development of energy snacks. The addition of VM showed a statistically high impact on protein, lipids, total dietary fiber contents, and total calories per portion. However, such types of foods should not be consumed daily or frequently. Additionally, VM showed a significant effect on the contents of free and bound PHC and the antioxidant activity, especially in the control and PC65 samples. This could possibly act as a limiting factor when compared with similar samples. Evaluation of sensory attributes demonstrated high acceptance by the panelists for all the developed formulations, as no differences were detected among the samples. 
Further analyses are required to corroborate the antioxidant effects and beneficial effects (digestibility) of the control and PC65 snacks on health via in vitro and in vivo analyses. The results for such kind of studies would aid in better understanding and development of different food formulations that include non-conventional ingredients and less processed foods for consumers.

Author Contributions: Conceptualization, methodology A.K.G.-C., N.A.G.-F. and A.S.E.-R.; methodology, supervision, M.Z.-L.; methodology, supervision, and editing, S.G.-L.; data curation, writingoriginal draft preparation, reviewing, and editing, N.P.-G. and A.E.-A. All authors have read and agreed to the published version of the manuscript.

Funding: This research received no external funding.

Institutional Review Board Statement: Not applicable.

Informed Consent Statement: Not applicable.

Acknowledgments: Thanks to Pascual Barba Ávila, and Wendy Rodríguez, from Nutrigrains ${ }^{\circledR}$, for donating the vegetal protein mixtures.

Conflicts of Interest: The authors declare no conflict of interest.

\section{References}

1. Constantin, E.O.; Istrati, I.D. Functional Properties of Snack Bars. In Functional Foods; Lagouri, V., Ed.; IntechOpen: Rijeka, Croatia, 2018; pp. 1-14. [CrossRef]

2. Rincón-León, F. Functional Foods. In Encyclopedia of Food Sciences and Nutrition, 2nd ed.; Benjamin, C., Ed.; Academic Press: Cambridge, MA, USA, 2003; pp. 2827-3232. [CrossRef]

3. Jew, S.; Abu Mweis, S.S.; Jones, P.J.H. Evolution of the Human Diet: Linking our Ancestral Diet to Modern Functional Foods as a Means of Chronic Disease Prevention. J. Med. Food 2009, 12, 925-934. [CrossRef]

4. Hernández, B.J.E.; León, J. Neglected Crops. 1942 from a Different Perspective; FAO (Food and Agriculture Organization): Rome, Italy, 1994; pp. 135-148. Available online: http:/ / www.fao.org/3/t0646e/t0646e.pdf (accessed on 3 September 2021).

5. Ogungbenle, H.N. Nutritional evaluation and functional properties of quinoa (Chenopodium quinoa) flour. Int. J. Food Sci. Nutr. 2003, 54, 153-158. [CrossRef] [PubMed]

6. Tang, Y.; Li, X.; Chen, P.X.; Zhang, B.; Liu, R.; Hernandez, M.; Draves, J.; Marcone, M.F.; Tsao, R. Assessing the fatty acid, carotenoid, and tocopherol compositions of amaranth and quinoa seeds grown in Ontario and their overall contribution to nutritional quality. J. Agric. Food Chem. 2016, 5, 1103-1110. [CrossRef] [PubMed]

7. Carciochi, R.A.; Marrique, G.D.; Dimitrov, K. Optimization of Antioxidant Phenolic Compounds Extraction from Quinoa (Chenopodium quinoa) Seeds. J. Food Sci. Technol. 2015, 52, 4396-4404. [CrossRef] [PubMed]

8. Tang, Y.; Li, X.; Chen, P.X.; Zhang, B.; Hernandez, M.; Zhang, H.; Marcone, M.F.; Liu, R.; Tsao, R. Lipids, Tocopherols, and Carotenoids in Leaves of Amaranth and Quinoa Cultivars and a New Approach to Overall Evaluation of Nutritional Quality Traits. J. Agric. Food Chem. 2014, 62, 12610-12619. [CrossRef] [PubMed]

9. Repo-Carrasco-Valencia, R.; Hellström, J.K.; Pihlava, J.-M.; Mattila, P.H. Flavonoids and other phenolic compounds in Andean indigenous grains: Quinoa (Chenopodium quinoa), kañiwa (Chenopodium pallidicaule) and kiwicha (Amaranthus caudatus). Food Chem. 2010, 120, 128-133. [CrossRef]

10. Mustafa, A.F.; Seguin, P.; Gélinas, B. Chemical composition, dietary fibre, tannins and minerals of grain amaranth genotypes. Int. J. Food Sci. Nutr. 2011, 62, 750-754. [CrossRef]

11. Gorinstein, S.; Vargas, O.J.M.; Jaramillo, N.O.; Salas, I.A.; Ayala, A.L.M.; Arancibia-Avila, P.; Toledo, F.; Katrich, E.; Trakhtenberg, S. The total polyphenols and the antioxidant potentials of some selected cereals and pseudocereals. Eur. Food Res. Technol. 2007, 225, 321-328. [CrossRef]

12. Magrone, T.; Russo, M.A.; Jirillo, E. Cocoa and dark chocolate polyphenols: From biology to clinical applications. Front. Immunol. 2017, 9, 677. [CrossRef]

13. USDA. Scientifc Report of the 2015 Dietary Guidelines Advisor Committee. Available online: https:/ /health.gov / sites/default/ files/2019-09/Scientific-Report-of-the-2015-Dietary-Guidelines-Advisory-Committee.pdf (accessed on 5 August 2021).

14. Rodriguez, N.R.; Miller, S.L. Effective translation of current dietary guidance: Understanding and communicating the concepts of minimal and optimal levels of dietary protein. Am. J. Clin. Nutr. 2015, 101, 1353S-1358S. [CrossRef]

15. Richter, C.K.; Skulas-Ray, A.C.; Champagne, C.M.; Kris-Etherton, P.M. Plant Protein and Animal Proteins: Do They Differentially Affect Cardiovascular Disease Risk? Adv. Nutr. 2015, 6, 712-728. [CrossRef] [PubMed]

16. FAO, Sustainable Food Systems. Concept and Framework. 2018. Available online: http://www.fao.org/3/ca2079en/CA2079EN pdf (accessed on 3 September 2021).

17. Małecki, J.; Tomasevic, I.; Djekic, I.; Sołowiej, B.G. The Effect of Protein Source on the Physicochemical, Nutritional Properties and Microstructure of High-Protein Bars Intended for Physically Active People. Foods. 2020, 9, 1467. [CrossRef] 
18. Veggi, N.; Voltarelli, F.A.; Pereira, J.M.N.; Silva, W.C.; Navalta, J.W.; Cavenaghi, D.F.L.D.C.; Barros, W.M.D. Quality of high-protein diet bar plus chia (Salvia hispanica L.) grain evaluated sensorially by untrained tasters. Food Sci. Technol. 2018, 38, 306-312. [CrossRef]

19. Nutrigrains ${ }^{\circledR}$. Products Data Sheets. Available online: https://nutrigrains.com.mx/productos.html\#provita-c (accessed on 20 August 2021).

20. Diario Oficial de la Federación. NOM-215-SSA1-2009. Prácticas de Higiene para el Proceso de Alimentos, Bebidas o Suplementos Alimenticios. Available online: http:/ /www.dof.gob.mx/normasOficiales/3980/salud/salud.htm (accessed on 20 August 2021).

21. AACCI (American Association of Cereal Chemists International). Approved Methods of the AACCI; American Association of Cereal Chemists: St. Paul, MN, USA, 2009.

22. ICUMSA (International Commission for Uniform Methods of Sugar Analysis). Methods of Sugar Analysis; Elsevier Publishing Company: New York, NY, USA, 1964; 166p. [CrossRef]

23. FAO (Food and Agriculture Organization). Food energy-Methods of analysis and conversion factors. In Proceedings of the Report of a Technical Workshop, Rome, Italy, 3-6 December 2002; FAO Food and Nutrition Paper 77; 87p. Available online: https://www.sennutricion.org/media/Docs_Consenso/Food_energy_methods_of_analysis_and_conversion_factorsFAO_2002.pdf (accessed on 3 September 2021).

24. Zavala-López, M.; García-Lara, S. An improved microscale method for extraction of phenolic acids from maize. Plant Methods 2017, 13, 1-11. [CrossRef]

25. Bergvinson, D.; García-Lara, S. Genetic approaches to reducing losses of stored grain to insects and diseases. Curr. Opin. Plant Biol. 2004, 7, 480-485. [CrossRef]

26. Hozová, B.; Zemanovič, J.; Chorvátová, R. Evaluation of the microbiological and sensory quality of amaranth-based biscuits. Prehrambeno-Technol. Rev. 1996, 33, 155-159.

27. Santos, T.C.; Bonomo, R.F.; Fontan, R.d.C.I.; Bonomo, P.; Veloso, C.M.; Fontan, G.C.R. Characterization and sensorial evaluation of cereal bars with jackfruit. Acta Sci. Technol. Mar. 2011, 33, 81-85. [CrossRef]

28. Caipo, I.Y.; Gutiérrez, F.A.; Julca, G.A. Optimización por diseño de mezclas de la aceptabilidad de una barra energética a base de quinua (Chenopodium quinoa), kiwicha (Amaranthus caudatus) y cañihua (Chenopodium pallidicaule) evaluada en niños. Agroind. Sci. 2015, 5, 61-67. [CrossRef]

29. Wu, G.; Morris, C.F.; Murphy, K.M. Quinoa starch characteristics and their correlations with the texture profile analysis (TPA) of Cooked Quinoa. J. Food Sci. 2017, 82, 2387-2395. [CrossRef]

30. Da Silva, E.C.; Sobrinho, A.D.S.; Cereda, M.P. Stability of casava flour-based food bars. Food Sci. Technol. Camp. 2013, 33, 192-198 [CrossRef]

31. Olivera, C.M.; Ferreyra, D.V.; Giacomino, M.S.; Curia, C.A.; Pellegrino, G.N.; Fournier, U.M.; Apro, C.N. Desarrollo de barras de cereales nutritivas y efecto del procesado en la calidad proteica. Rev. Chil. Nutr. 2012, 39, 18-25. [CrossRef]

32. Araya, H.; Pak, N.; Vera, G.; Alviña, M. Digestion rate of legume carbohydrates and glycemic index of legume-based meals. Int. J. Food Sci. Nutr. 2003, 54, 119-126. [CrossRef] [PubMed]

33. Vega-Gálvez, A.; Miranda, M.; Vergara, J.; Uribe, E.; Puente, L.; Martínez, E.A. Nutrition facts and functional potential of quinoa (Chenopodium quinoa willd.), an ancient Andean grain: A review. J. Sci. Food Agric. 2010, 90, 2541-2547. [CrossRef] [PubMed]

34. Mishra, G.; Joshi, D.C.; Kumar, P.B. Popping and puffing of cereal grains: A review. J. Grain Process. Storage 2014, 1, $34-46$.

35. Ponce-García, N.; Escalante-Aburto, A.; Santiago-Ramos, D. Mariscal-Moreno, R.M. Quinoa grains processing: Effects on its physicochemical properties. In Super and Nutraceutical Foods: Composition and Technology; Sandra, T.M.C., Jessica, P.R.A., Anaberta, C.M., Eds.; NOVA Publishers: New York, NY, USA, 2021; pp. 253-268. ISBN 978-1-53619-082-3.

36. Nilsson, A.C.; Ostman, E.M.; Granfeldt, Y.; Björck, I.M. Effect of cereal test breakfasts differing in glycemic index and content of indigestible carbohydrates on daylong glucose tolerance in healthy subjects. Am. J. Clin. Nutr. 2008, 87, 645-654. [CrossRef]

37. Zupanič, N.; Miklavec, K.; Kušar, A.; Žmitek, K.; Fidler Mis, N.; Pravst, I. Total and free sugar content of pre-packaged foods and non-alcoholic beverages in Slovenia. Nutrients 2018, 10, 151. [CrossRef]

38. Sant'Ana, R.d.C.O.; Mendes, F.Q.; Pires, C.V.; Oliveira, M.G.d.A. Influence of lipid extraction from different protein sources on in vitro digestibility. Cien. Agrotec. 2011, 35, 758-764. [CrossRef]

39. Srebernich, S.M.; Gonçalves, G.M.S.; Ormenese, R.d.C.S.C.; Ruffi, C.R.G. Physico-chemical, sensory and nutritional characteristics of cereal bars with addition of acacia gum, inulin and sorbitol. Food Sci. Technol. 2016, 36, 555-562. [CrossRef]

40. FAO/WHO/ONU. Protein and Amino Acid Requirements in Human Nutrition: Report of a Joint FAO/WHO/UNU Expert Consultation. Available online: https://apps.who.int/iris/bitstream/handle/10665/43411/WHO_TRS_935_eng.pdf?sequence= 1\&isAllowed=y (accessed on 8 April 2019).

41. Torres-Moreno, M.; Torrescasana, E.; Salas-Salvadó, J.; Blanch, C. Nutritional composition and fatty acids profile in cocoa beans and chocolates with different geographical origin and processing conditions. Food Chem. 2015, 166, 125-132. [CrossRef]

42. FAO (Food and Agriculture Organization). Fats and fatty acids in human nutrition. In Proceedings of the Report of an Expert Consultation, Geneva, Switzerland, 10-14 November 2008; Food and Agriculture Organization of the United Nations: Rome, Italy, 2008. 166p.

43. Lamothe, L.M.; Srichuwong, S.; Reuhs, B.L.; Hamaker, B.R. Quinoa (Chenopodium quinoa W.) and amaranth (Amaranthus caudatus L.) provide dietary fibres high in pectic substances and xyloglucans. Food Chem. 2015, 167, 490-496. [CrossRef] 
44. FDA (Food and Drug Administration). Dietary Fiber. Available online: https://www.accessdata.fda.gov/scripts/ interactivenutritionfactslabel/dietary-fiber.html (accessed on 8 April 2019).

45. Green, H.; Siwajek, P.; Roulin, A. Use of nutrient profiling to identify healthy versus unhealthy snack foods and whether they can be part of a healthy menu plan. J. Nutr. Intermed. Metab. 2017, 9, 1-5. [CrossRef]

46. Njike, V.Y.; Smith, T.M.; Shuval, O.; Shuval, K.; Edshteyn, I.; Kalantari, V.; Yaroch, A.L. Snack food, satiety, and weight. Adv. Nutr. 2016, 7, 866-878. [CrossRef] [PubMed]

47. Williamson, G.; Holst, B. Dietary reference intake (DRI) value for dietary polyphenols: Are we heading in the right direction? Br. J. Nutr. 2008, 3, S55-S58. [CrossRef]

48. Liu, M.; Zhu, K.; Yao, Y.; Chen, Y.; Guo, H.; Ren, G.; Yang, X.; Li, J. Antioxidant, anti-inflammatory, and antitumor activities of phenolic compounds from white, red, and black Chenopodium quinoa seed. Cereal Chem. 2020, 97, 703-713. [CrossRef]

49. Stikić, R.I.; Milinčić, D.; Kostić, A.Ž.; Jovanović, Z.B.; Gašić, U.; Tešić, Ž.L.; Djordjević, N.Z.; Savić, S.K.; Czekus, B.G.; Pešić, M. Polyphenolic profiles, antioxidant, and in vitro anticancer activities of the seeds of Puno and Titicaca quinoa cultivars. Cereal Chem. 2020, 97, 626-633. [CrossRef]

50. Karunasiri, A.N.; Gunawardane, M.; Senanayake, C.M.; Jayathilaka, N.; Seneviratne, K.N. Antioxidant and nutritional properties of domestic and commercial coconut milk preparations. Int. J. Food Sci. 2020, 2020, 3489605. Available online: https:/ / www.ncbi. nlm.nih.gov/pmc/articles/PMC7422486/ (accessed on 3 September 2021). [CrossRef]

51. Melini, V.; Melini, F. Modelling and Optimization of Ultrasound-assisted extraction of phenolic compounds from black quinoa by response surface methodology. Molecules. 2021, 26, 3616. [CrossRef]

52. Carciochi, R.A.; Dimitrov, K.; Galván D'Alessandro, L. Effect of malting conditions on phenolic content, Maillard reaction products formation, and antioxidant activity of quinoa seeds. J. Food Sci. Technol. 2016, 53, 3978-3985. [CrossRef]

53. Marques, T.R.; Corrêa, A.D.; de Carvalho Alves, A.P.; Simão, A.A.; Pinheiro, A.C.M.; de Oliveira Ramos, V. Cereal bars enriched with antioxidant substances and rich in fiber, prepared with flours of acerola residues. J. Food Sci. Technol. 2015, 52, 5084-5092. [CrossRef]

54. Bisharat, G.I.; Lazou, A.E.; Panagiotou, N.M.; Krokida, M.K.; Maroulis, Z.B. Antioxidant potential and quality characteristics of vegetable-enriched corn-based extruded snacks. J. Food Sci. Technol. 2015, 52, 3986-4000. [CrossRef]

55. Silva Carvalho, V.; Conti-Silva, A.C. Storage study of cereal bars formulated with banana peel flour. Nutr. Food Sci. 2018, 48, 386-396. [CrossRef]

56. Ahmed, Z.S.; Abozed, S.S. Functional and antioxidant properties of novel snack crackers incorporated with Hibiscus sabdariffa by-product. J. Adv. Res. 2015, 6, 79-87. [CrossRef]

57. Jalil, A.M.; Ismail, A. Polyphenols in cocoa and cocoa products: Is there a link between antioxidant properties and health? Molecules 2008, 13, 2190-2219. [CrossRef]

58. Buitimea-Cantúa, N.E.; Gutiérrez-Uribe, J.A.; Serna-Saldívar, S.O. Phenolic-protein interactions: Effects on food properties and health benefits. J. Med. Food. 2018, 21, 188-198. [CrossRef] [PubMed]

59. Sęczyk, L.; Świeca, M.; Kapusta, I.; Gawilk-Dziki, U. Protein-phenolic interactions as a factor affecting the physicochemical properties of white bean proteins. Molecules 2019, 24, 408. [CrossRef] [PubMed]

60. Perez-Gregorio, M.R.; Simal-Gandara, J. A Critical review of the characterization of polyphenol-protein interactions and of their potential use for improving food quality. Curr. Pharm. Des. 2017, 23, 2742-2753. [CrossRef]

61. Velickovic, T.D.C.; Stanic-Vucinic, D. The role of dietary phenolic compounds in protein digestion and processing technologies to improve their antinutritive properties. Compr. Rev. Food Sci. Food Saf. 2018, 17, 82-103. [CrossRef]

62. Rosales, S.M.U.; Brown, K.; Ross, C.F. Antioxidant activity and consumer acceptance of grape seed flour-containing food products. Int. J. Food Sci. Technol. 2012, 47, 592-602. [CrossRef]

63. Laokuldilok, N.; Thakeow, P.; Kopermsub, P.; Utama-ang, N. Quality and antioxidant properties of extruded breakfast cereal containing encapsulated turmeric extract. Chiang Mai J. Sci. 2015, 42, 1-11.

64. Durazzo, A.; Casale, G.; Melini, V.; Maiani, G.; Acquistucci, R. Evaluation of antioxidant properties in cereals: Study of some traditional Italian wheats. Foods 2015, 4, 391-399. [CrossRef] 